\title{
Sinergi Pelayanan Zakat dan Pajak Dalam Upaya Mengurangi Kemiskinan
}

\section{Jumi Herlita}

UIN Antasari Banjarmasin

\begin{abstract}
Zakat and taxes are two important sources of funding for the state. Both function to solve economic problems and reduce poverty in the community. But in reality the function of zakat and tax can not be optimal. BAZNAS and LAZ as an extension of the government in managing zakat can not be maximized in the collection of zakat funds as well as taxes. Although the nature of the tax is not specific to the poor, but also to the rich, but in fact the existence of taxes have not been able to solve poverty in Indonesia. Therefore it is necessary solution to synergize zakat and tax in order to increase zakat and tax collection. With bersinerginya zakat and taxes are expected to increase public awareness to pay zakat and taxes that can eventually be used to reduce poverty.

Keyword: Sinergi, Zakat, Tax, Poverty
\end{abstract}

\section{Pendahuluan}

Indonesia adalah negara yang memiliki sumber daya alam yang melimpah tetapi yang terjadi kekayaan itu tidak otomatis membuat rakyat sejahtera sebaliknya yang terjadi adalah masalah kemiskinan menjadi musuh utama negeri ini. Banyak kebijakan yang telah dikeluarkan oleh pemerintah dalam upaya mengurangi angka kemiskinan, diantaranya mulai dari kebijakan fiskal dengan mengalokasikan dana baik APBN maupun APBD melalui bantuan sosial, Program Perlindungan Sosial melalui Program Keluarga Harapan, penyediaan Kartu Keluarga Sejahtera (KKS), program beras miskin (raskin), Kartu Indonesia Sejahtera (KIS), layanan beasiswa kurang mampu melalui Kartu Indonesia Pintar (KIP) dan program SJSN ketenagakerjaan.

Angka kemiskinan di Indonesia berdasarkan data dari Badan Pusat Statistik (BPS), diketahui masih sangat tinggi, data tersebut dapat dilihat pada tabel 1 . 
Tabel 1. Kemiskinan di Indonesia

\begin{tabular}{ccccc}
\hline \multirow{2}{*}{ Tahun } & Jumlah Penduduk & Persentase Penduduk & \multicolumn{2}{c}{$\begin{array}{c}\text { Garis Kemiskinan } \\
\text { (Rp/Kapita/Bulan) }\end{array}$} \\
& Miskin (Juta Orang) & Miskin (\%) & Kota & Desa \\
\hline September 2011 & 29.89 & 12.36 & 263594 & 223181 \\
September 2012 & 28.59 & 11.66 & 277382 & 240441 \\
September 2013 & 28.55 & 11.47 & 308826 & 275779 \\
September 2014 & 27.73 & 10.96 & 326853 & 296681 \\
September 2015 & 28.51 & 11.13 & 356378 & 333034 \\
September 2016 & 27.76 & 10.70 & 372114 & 350420 \\
\hline
\end{tabular}

Sumber : Badan Pusat Statistik

Berdasarkan data pada tabel 1, diketahui bahwa jumlah penduduk miskin dari tahun 20112016 mengalami penurunan dengan persentase rata-rata diantara 10\%-12\%. Meskipun data menunjukkan penurunan angka kemiskinan tetapi angka kemiskinan itu dibayang-bayangi oleh tingginya kesenjangan antar penduduk di kawasan perkotaan dengan penduduk di pedesaan dimana tingkat kemiskinan di perkotaan lebih besar daripada di pedesaan. Hal ini tentunya perlu mendapat perhatian besar dari pemerintah. Selain itu tingginya tingkat kemiskinan ini juga disumbang oleh jumlah pengangguran yang terus meningkat. Data pengangguran yang diduga sebagai penyebab kemiskinan dapat dilihat pada tabel 2

:Tabel 2 Tingkat Pengangguran Terbuka Berdasarkan Pendidikan

\begin{tabular}{|c|c|c|c|c|c|c|c|c|c|}
\hline \multirow{2}{*}{ No. } & \multirow{2}{*}{$\begin{array}{l}\text { Pendidikan Tertinggi } \\
\text { Yang Ditamatkan }\end{array}$} & \multicolumn{2}{|c|}{2012} & \multicolumn{2}{|c|}{2013} & \multicolumn{2}{|c|}{2014} & \multicolumn{2}{|c|}{2015} \\
\hline & & Februari & Agustus & Februari & Agustus & Februari & Agustus & Februari & Agustus \\
\hline 1 & $\begin{array}{l}\text { Tidak/belum pernah } \\
\text { sekolah }\end{array}$ & 126,972 & 85,374 & 112,435 & 81,432 & 134,040 & 74,898 & 124,303 & 55,554 \\
\hline 2 & Tidak/belum tamat SD & 601,753 & 512,041 & 523,400 & 489,152 & 610,574 & 389,550 & 603,194 & 371,542 \\
\hline 3 & SD & $1,418,683$ & $1,452,047$ & $1,421,873$ & $1,347,555$ & $1,374,822$ & $1,229,652$ & $1,320,392$ & $1,004,961$ \\
\hline 4 & SLTP & $1,736,670$ & $1,714,776$ & $1,821,429$ & $1,689,643$ & $1,693,203$ & $1,566,838$ & $1,650,387$ & $1,373,919$ \\
\hline 5 & SLTA Umum/SMU & $2,043,697$ & $1,867,755$ & $1,874,799$ & $1,925,660$ & $1,893,509$ & $1,962,786$ & $1,762,411$ & $2,280,029$ \\
\hline 6 & SLTA Kejuruan/SMK & $1,018,465$ & $1,067,009$ & 864,649 & $1,258,201$ & 847,365 & $1,332,521$ & $1,174,366$ & $1,569,690$ \\
\hline 7 & Akademi/Diploma & 258,385 & 200,028 & 197,270 & 185,103 & 195,258 & 193,517 & 254,312 & 251,541 \\
\hline 8 & Universitas & 553,206 & 445,836 & 425,042 & 434,185 & 398,298 & 495,143 & 565,402 & 653,586 \\
\hline & Total & $7,757,831$ & $7,344,866$ & $7,240,897$ & $7,410,931$ & $7,147,069$ & $7,244,905$ & $7,454,767$ & $\mathbf{7 , 5 6 0 , 8 2 2}$ \\
\hline
\end{tabular}

Sumber : Badan Pusat Statistik

Dari tabel 2, dapat diketahui bahwa angka pengangguran di Indonesia masih tinggi sehingga dikhawatirkan akan menjadi penyebab berbagai tindakan yang dapat merusak berbagai sendi 
kehidupan, seperti rendahnya moral, rusaknya pemikiran, dan rusaknya kehidupan sosial masyarakat, sehingga diperlukan perhatian yang serius dari berbagai pihak terutama untuk mengurangi kemiskinan.

Bagaimanapun, Indonesia merupakan negara yang mempunyai banyak potensi yang bisa digali untuk memajukan perekonomiannya. Dari sisi agama, Islam memiliki solusi untuk penanganan kemiskinan yaitu dengan mendorong perkembangan zakat dan dari sisi negara dengan kewajiban membayar pajak. Zakat dan pajak adalah dua kewajiban yang harus dijalankan oleh setiap Muslim karena sudah ada perintah dan aturannya. Kalau zakat merupakan perintah dari Allah yang aturannya terdapat pada Alquran dan Hadist, sedangkan pajak dari negara yang aturannya ada dalam undang-undang (UU) dan peraturan-peraturan. Namun, tidak sedikit yang mengabaikan kedua kewajiban itu. Ada juga yang hanya melaksanakan satu kewajiban saja, berzakat tapi tidak bayar pajak. Atau, bayar pajak tapi tak berzakat.

Zakat dan pajak sebagai sumber dana yang penting bagi negara merupakan salah satu solusi untuk mengurangi kemiskinan. Namun perkembangan zakat tidak sebaik dengan pajak karena zakat ditunaikan berdasarkan iman atau kesukarelaan, selain itu juga tidak ada kontrol dan pemberian sanksi bagi pelanggarnya, maka pembayarannya pun tidak jarang terabaikan atau tergantung pada tingkat ketaqwaan seseorang. Dalam hal ini, zakat kalah pengaruh oleh pajak. Hal inilah yang seringkali menjadi kendala utama dalam meningkatkan jumlah penerimaan zakat pada lembaga-lembaga pengumpul zakat. Kenyataan tersebut berbeda sekali dengan pajak, yang karena didorong secara imperatif oleh negara, pembayarannya selalu dilunasi setiap jatuh tempo. Bagi yang terlambat, ditegur, bagi yang membayar tepat pada waktunya, diberikan diskon khusus atau diberi penghargaan. Di negara Barat, bagi orang yang tidak membayar pajak atau menggelapkan pajak, dapat dihukum pidana dengan hukuman yang cukup berat ${ }^{1}$.

Wacana sinergi antara zakat dan pajak telah digagas lama, baik dalam dunia akademik maupun kebijakan. Sebuah pernyataan menarik dilontarkan oleh Menteri Keuangan Sri Mulyani Indrawati dalam acara 2nd Annual Islamic Finance Conference (AIFC) 2017 yang digelar oleh Kementerian Keuangan di Yogyakarta. Menteri keuangan mengungkapkan, pengelolaan dana zakat di Indonesia masih belum dilakukan secara optimal, padahal sistemnya bisa dilakukan sama

\footnotetext{
${ }^{1}$ https://www.kompasiana.com/zayfawwaz/59a581b0f133440ba521f482/sinergitas-pajak-dan-zakat-dalamkeuangan-islam
} 
seperti pemerintah mengelola dana pajak ${ }^{2}$. Hal ini menjadi sinyal yang baik bagi lembagalembaga zakat untuk mendorong proses sinergi antara zakat dan pajak agar terwujud berbagai program-program pembangunan, khususnya pengentasan kemiskinan, pembangunan infrastruktur, dan peningkatan kesejahteraan rakyat.

Oleh karena itu, dalam tulisan ini penulis membahas beberapa hal yang dapat dilakukan pihak-pihak terkait seperti pemerintah selaku pengambil kebijakan dan lembaga-lembaga zakat sebagai penghimpun, penyalur dan pendayaguna zakat untuk dapat mensinergikan zakat dan pajak dalam upaya untuk mengurangi kemiskinan.

Kerangka Berfikir

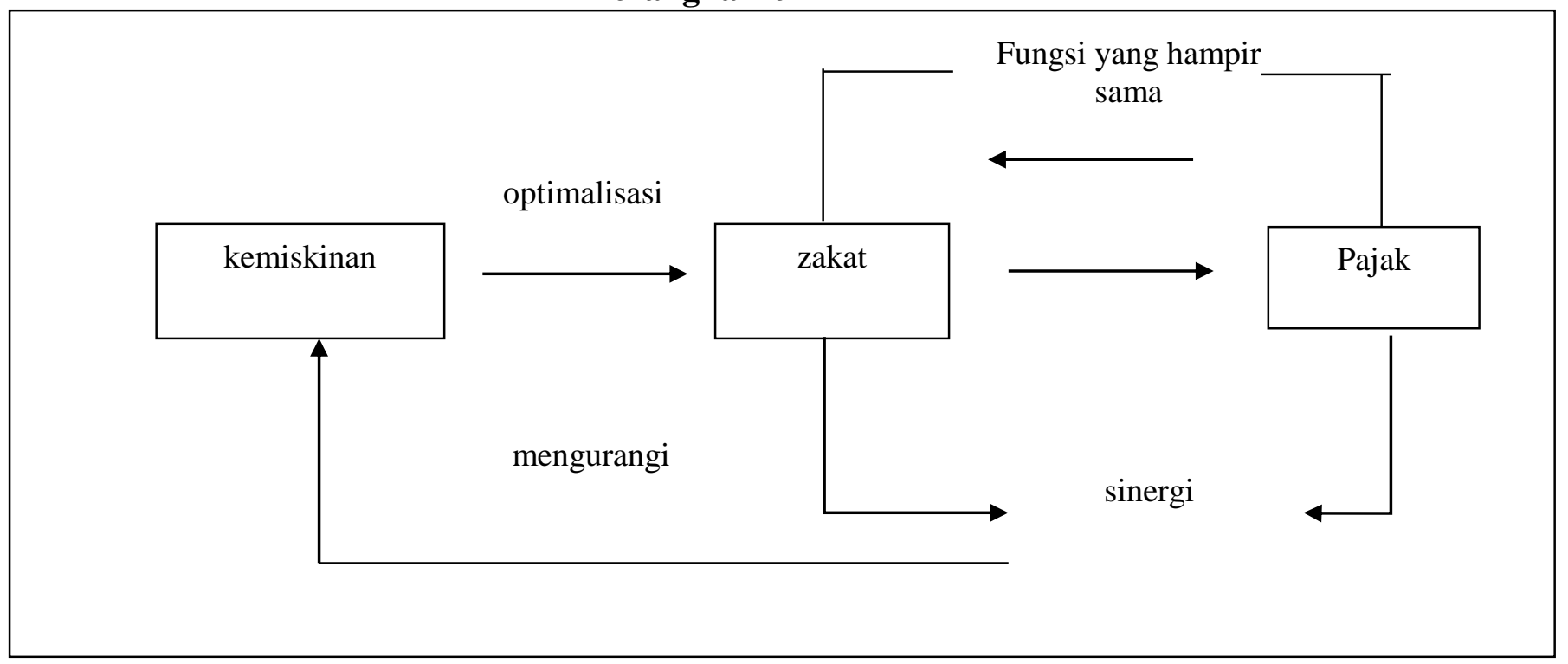

\section{Pembahasan}

\section{Pengertian Zakat dan Pajak}

Zakat dalam agama Islam pada hakikatnya adalah sebagai bagian dari harta yang dimiliki oleh seorang Muslim yang wajib dikeluarkan atas perintah Allah untuk dipergunakan sebagai kepentingan orang lain yang berhak menerimanya sesuai dengan kadar yang telah ditentukan oleh syariat. Jadi zakat adalah kewajiban atas harta yang bersifat mengikat dan bukan anjuran. Di sisi lain, dalam kaitannya dengan hal yang seirama dengan zakat, dalam konteks kenegaraan, pajak

\footnotetext{
${ }^{2}$ http://www.republika.co.id/berita/jurnalisme-warga/wacana/17/08/30/ovibjm396-sinergi-pelayanan-zakat-danpajak
} 
merupakan kewajiban material yang harus dibayarkan oleh masyarakat suatu negara menurut ukuran yang telah ditentukan atas kekayaan pribadi seseorang untuk dipergunakan sebagai pengeluaran suatu negara ${ }^{3}$.

Jadi kewajiban pajak dan kewajiban zakat memiliki dua dasar pijakan yang berlainan. Zakat mengacu pada ketentuan syariat atau hukum Allah SWT baik dalam pemungutan dan penggunaannya, sedang pajak berpijak pada peraturan perundang-undangan yang ditentukan oleh Ulil Amri/pemerintah menyangkut pemungutan maupun penggunaannya.

\section{Dasar dan tujuan Kewajiban Zakat dan Pajak}

Kewajiban zakat bersumber dari wahyu Allah SWT, yakni dalam QS Al-Baqarah ayat 83 yang artinya: “dan (ingatlah), ketika Kami mengambil janji dari Bani Israil (yaitu): janganlah kamu menyembah selain Allah, dan berbuat kebaikanlah kepada ibu bapa, kaum kerabat, anakanak yatim, dan orang-orang miskin, serta ucapkanlah kata-kata yang baik kepada manusia, dirikanlah shalat dan tunaikanlah zakat. Kemudian kamu tidak memenuhi janji itu, kecuali sebagian kecil daripada kamu, dan kamu selalu berpaling. "

Oleh karena itu zakat adalah kewajiban dan merupakan salah satu dari rukun Islam. Walaupun di dalamnya terdapat unsur kewajiban materi, kedudukannya adalah sebagai ibadah yang setaraf dengan ibadah-ibadah lainnya. Kewajiban ini khusus diberikan kepada orang Islam. Karena kedudukannya sebagai ibadah menjadikan umat Islam termotivasi untuk melaksanakannya ${ }^{4}$.

Sedangkan kewajiban pajak bersumber dari aturan perundang-undangan yang ditetapkan pemerintah melalui badan yang berwenang untuk itu, dimana pajak merupakan kewajiban pribadi atau badan yang berlaku bagi setiap warga Negara. Bagi umat Islam kedua kewajiban itu adalah sama, meskipun dari segi motivasi pelaksanaannya, zakat lebih kuat meskipun tanpa sanksi, karena hubungannya antara hamba dengan Allah. Pada pajak hanya terdapat hubungan antara hamba dengan penguasa Negara yang mewajibkan pajak tersebut.

\footnotetext{
${ }^{3}$ Afriyandi, Yuli, Sinergitas Pajak dan Zakat dalam Keuangan Publik Islam(Analisis Historis dan Kondisi Kekinian, Jurnal Rasail, Vol 1, No 2, 2014.

${ }^{4}$ Afriyandi, Yuli, Sinergitas Pajak dan Zakat dalam Keuangan Publik Islam(Analisis Historis dan Kondisi Kekinian, Jurnal Rasail, Vol 1, No 2, 2014.
} 
Kewajiban zakat mengandung tujuan yang bersifat moral spiritual. Seorang muslim merasa menjalankan kewajiban agama yang harus dipikulnya sekaligus menyadari bahwa harta yang dimilikinya adalah milik Allah Swt. Dalam mensyukuri nikmat Allah itu, seorang muslim harus mengeluarkan sebagian dari harta yang dimilikinya untuk tujuan yang sesuai dengan kehendak Allah Swt.

Tujuan moral terlihat dari segi anggapan bahwa sesama hamba Allah yang bersaudara harus memiliki kepedulian, saling tolong-menolong dan kasih sayang di antara sesama. Zakat dikeluarkan dalam rangka mewujudkan kesatuan dan persatuan serta melaksanakan demokrasi ekonomi, dengan menghindarkan diri dari terjadinya penumpukan asset dan pemusatan ekonomi pada seseorang, sekelompok orang atau perusahaan yang tidak sesuai dengan prinsip keadilan dan pemerataan.

Pada pajak terlihat tujuan yang lebih bersifat material, yaitu sebanyak mungkin memasukkan materi ke dalam kas negara untuk membiayai kebutuhan negara. Dalam hal ini terkandung suatu pemikiran bahwa warga negara yang mendapat keuntungan dan perlindungan dalam negara harus mengimbanginya dengan membantu negara.

\section{Integrasi zakat dan pajak menurut pandangan ulama}

Melihat sejarah pada zaman Nabi dan khalifah sesudahnya, zakat merupakan satu-satunya sistem perpajakan bagi umat Islam di luar kharaj yakni pajak atas tanah. Sekarang umat Islam berada pada abad 21 dengan situasi dan kondisi yang sangat berbeda dari masa lalu. Kita hidup di dunia modern dengan sistem perpajakan yang persentasenya lebih tinggi dari persentase zakat.

Dalam kaitan ini, pertanyaan yang sering muncul adalah apakah masih wajib zakat atas harta yang telah kena pajak, apakah boleh membayar pajak dengan niat zakat, dan berbagai pertanyaan lainnya. Berangkat dari sebuah wacana, perdebatan ini telah memicu polemik pemikiran diantara ulama.

Abu zahrah misalnya, mengemukakan bahwa pajak-pajak itu sampai sekarang tidak memiliki nilai-nilai khusus yang dapat memberikan jaminan sosial. Itulah mula-mula yang menjadi tuntunan zakat. Zakat dapat memenuhi tuntutan pajak, akan tetapi pajak tidak dapat 
memenuhi tuntutan zakat, karena pajak tidak menanggulangi kebutuhan fakir miskin yang menuntut untuk dipenuhi ${ }^{5}$

Menurut Masdar Farid Mas'udi, pemikirannya untuk mengintegrasikan zakat dan pajak menimbulkan kontroversi dan pertanyaan yang cukup beragam karena mencoba untuk menyatukan dua hal yang secara substansi dan kegunaannya berbeda. Menurutnya, umat Islam yang telah membayar pajak, tidak wajib lagi membayar zakat. Karena permasalahan double tax menjadi beban bagi umat Islam. Karenanya kalau pajak yang dibayarkan telah diniatkan sebagai zakat tidak perlu lagi untuk membayar zakat ${ }^{6}$.

Sedangkan menurut Ibrahim Hosen (1990) dan ulama-ulama umumnya yang menyatakan bahwa zakat tidak bisa dipajakkan, begitu pula pajak tidak bisa dizakatkan, maka seorang muslim wajib menjalankan kedua kewajiban ini $^{7}$. Tidak dapat dijadikan dalil bahwa apabila zakat telah dibayar maka zakat menjadi gugur. Warga Negara Indonesia yang beragama Islam berkewajiban mengeluarkan zakat sebagai realisasi ketaatan kepada pemerintah yang juga diwajibkan oleh agama. Islam memberi wewenang kepada pemerintah untuk mengelola zakat dan pajak.

a. Persamaan zakat dan pajak

Dapat dipetik beberapa persamaan dari zakat dan pajak, yaitu

1. Bersifat wajib dan mengikat atas harta penduduk suatu negeri, apabila melalaikannya terkena sanksi.

2. Zakat dan pajak harus disetorkan pada lembaga resmi agar tercapai efisiensi penarikan keduanya dan alokasi penyalurannya. Dalam pemerintahan Islam, zakat dan pajak dikelola oleh negara.

3. Tidak ada ketentuan memperoleh imbalan materi tertentu di dunia.

4. Dari sisi tujuan ada kesamaan antara keduanya yaitu untuk menyelesaikan problem ekonomi dan mengentaskan kemiskinan yang terdapat di masyarakat.

\footnotetext{
${ }^{5}$ Salamah, Siti Ummu, Relasi Zakat dan Pajak: Studi Kasus Badan Amil Zakat Nasional Kabupaten Malang dan Kantor Pelayanan Pajak Pratama Kepanjen Malang, Jurnal Hukum dan Syariah Vol.6 No 1, 2015.

${ }^{6}$ Mas'udi, Masdar Farid, Pajak Itu Zakat: Uang Allah untuk Kemaslahatan Rakyat, Bandung: Mizan Media Utama, 2010.

${ }^{7}$ Firmansyah, Zakat Sebagai Instrumen Pengetasan Kemiskinan Dan Kesenjangan Pendapatan, jurnal Ekonomi dan Pembangunan Vol 21, No.2, Desember 2013.
} 


\section{b. Perbedaan Zakat dan Pajak}

Adapun perbedaan-perbedaan yang cukup mendasar antara zakat dan pajak adalah sebagai berikut :

1. Beda dasar hukum. Dasar hukum zakat adalah al-Qur'an dan Sunnah, sedangkan dasar hukum pajak adalah peraturan perundang-undangan seperti Undang-undang Pajak dan sebagainya.

2. Beda status hukumnya. Zakat adalah suatu kewajiban terhadap agama, sedangkan pajak adalah suatu kewajiban terhadap Negara.

3. Beda objek/sasarannya. Wajib zakat adalah khusus bagi penduduk beragama Islam, sedangkan wajib pajak adalah bagi semua penduduk tanpa pandang agamanya.

4. Beda kriterianya. Kriteria pendapatan dan kekayaan yang terkena zakat dan pajak, prosentasinya dan jatuh temponya tidaklah sama. Misalnya presentasi penghasilan yang dizakati adalah antara 2,5\%-20\% tergantung pada jenis usaha/pekerjaan/profesinya, yang sudah ditentukan kadarnya oleh agama dan tidak bisa diubah-ubah, sedangkan prosentase penghasilan yang terkena pajak di Indonesia sekitar 15\%-25\% dan sudah tentu criteria wajib pajak juga besarnya tarif pajak bisa berubah-ubah.

5. Beda pos-pos penggunaannya. Zakat hanya boleh digunakan untuk delapan pos/ashnaf yang sudah ditentukan al-Qur'an surat at-taubah ayat 60, sedangkan pajak digunakan untuk pos-pos yang sangat luas.

6. Beda hikmahnya. Hikmah zakat terutama untuk membersihkan/menyucikan jiwa dan harta benda wajib zakat, untuk meratakan pendapatan di kalangan masyarakat (agar tidak hanya dinikmati si kaya saja, dan untuk meningkatkan kesejahteraan sosial, sedangkan hikmah pajak adalah untuk membiayai pembangunan nasional guna mewujudkan suat masyarakat adil dan makmur berdasarkan pancasila yang diridhai Allah Swt.

\section{c. Solusi Sinergi Zakat dan Pajak}

Optimalisasi zakat dan pajak merupakan suatu keharusan sebagai upaya dalam pengentasan kemiskinan. Pemungutan zakat dan pajak diharapkan bisa saling bersinergi sehingga penggalian 
potensi kedua sumber dana tersebut dapat maksimal. Sinergi antara keduanya tetap harus berjalan dalam peraturan yang harmonis dan tidak saling bertentangan.

Dapat dibayangkan bagaimana kalau kedua hal ini (zakat dan pajak) berjalan dengan baik. Penduduk Indonesia yang mayoritas beragama Islam membayar zakat, tidak hanya zakat fitrah tetapi juga zakat maal. Zakat tersebut lalu disalurkan kepada orang yang berhak menerimanya. Begitu juga dengan pajak, apabila target yang dimiliki pemerintah terhadap jumlah pajak yang seharusnya diterima tanpa adanya penyelewengan-penyelewengan terhadap pajak maka pembangunan Indonesia akan berjalan dengan baik.

Untuk mewujudkan sinergi antara zakat dan pajak untuk kemaslahatan umat adalah tidak hanya yang tertuang dalam perundang-undangan, akan tetapi perlu skema lain yang lebih aplikatif. Hal-hal yang dapat dilakukan antara lain :

Pertama, kolaborasi program sosialisasi dan edukasi antara pemerintah melalui Dirjen Pajak dan BAZNAS sebagai amil resmi zakat nasional tentang zakat dan pajak secara terus menerus sehingga setiap muslim sadar akan kewajibannya. Baik sebagai muslim yang taat kepada perintah Allah dan Rasul maupun kepada ulil amri. Sosialisasi dan edukasi melalui program-program penyuluhan, promosi informasi di mediasangat penting dilakukan mengingat mau tidaknya seorang Muslim membayar zakat dan pajak sangat dipengaruhi oleh pemahamannya terhadap persamaan dan perbedaan antara zakat dan pajak. Bila dia memahami zakat dan pajak tidak ada perbedaannya karena sama-sama demi kemaslahatan umat dan bangsa, maka ia akan hanya membayar zakat saja. Bila tidak ada upaya penyadaran dikhawatirkan masyarakat akan terus ragu. Dengan demikian, manfaat peningkatan penerimaan zakat dan pajak tersebut dapat maksimal sehingga berdampak positif bagi program pengentasan kemiskinan.

Kedua, penyediaan fasilitas pengelolaan zakat di Kantor Pelayanan Zakat (KPP). Dengan mengadakan kerjasama antara BAZNAS dengan KPP untuk pemanfaatan KPP dalam pengelolaan zakat. Fasilitas yang disediakan akan mempermudah setiap Muslim yang membayar pajak untuk langsung berzakat di tempat tersebut. Selain itu, dapat mempermudah akses dalam penyerahan bukti penerimaan zakat yang dipergunakan untuk lampiran SPT tahunan PPh yang bersangkutan.

Ketiga, menjalin koordinasi yang baik antara otoritas pajak. Hal ini akan membuat identifikasi muzaki dan wajib pajak semakin meluas sehingga diharapkan pendapatan pajak dan zakat akan semakin meningkat. Koordinasi yang terjalin dengan baik akan menghasilkan pemberlakuan kebijakan zakat sebagai kredit pajak secara ideal. Selain itu hal yang perlu 
diperhatikan untuk meningkatkan koordinasi adalah pemusatan pengelolaan zakat pada satu lembaga yang secara resmi dan sah ditunjuk oleh pemerintah untuk mengelola sekaligus menjadi regulator, misalnya BAZNAS

Keempat, penerapan zakat sebagai pengurang pajak secara langsung. Hal ini merupakan langkah yang strategis dalam upaya menggali potensi zakat, sekaligus mengintegrasikannya secara lebih mendalam dalam perekonomian nasional. Menurut Didin Hafiduddin apabila zakat sebagai pengurang pajak dapat terealisasi ada dua manfaat yang diperoleh negara yaitu pertama, dengan adanya koordinasi yang baik antara otoritas zakat dengan otoritas pajak, maka indentifikasi wajib zakat (muzakki) dan wajib pajak akan semakin luas. Sehingga diharapkan pendapatan pajak dan zakat semakin meningkat. Kedua, membantu meringkankan beban APBN khususnya dalam anggaran pengentasan kemiskinan.

Kelima, idealnya zakat dikelola oleh pemerintah yaitu dibawah koordinasi langsung Presiden melalui Menteri Keuangan/ Badan Penerimaan Negara dan perlu berkoordinasi dengan Badan Amil Zakat juga Lembaga Amil Zakat, hal ini bertujuan supaya terjadi optimalisasi pemungutan dan penyalurannya.

Dengan adanya sinergi antara zakat dan pajak maka akan terjadi efektivitas peningkatan kesadaran masyarakat untuk membayar zakat dan juga pajak sehingga tujuan yang ingin dicapai oleh pemerintah dalam upaya mengurangi kemiskinan akan dapat terwujud.

\section{Simpulan}

Indonesia memiliki potensi zakat yang sangat besar jumlahnya. Namun, realisasi zakat yang terkumpul pada lembaga amil zakat pemerintah maupun swasta masih sangat kecil jumlahnya. Hal ini terjadi karena beberapa hal, mulai dari kesadaran masyarakat untuk membayar zakat melalui lembaga maupun tingkat kepercayaan yang masih rendah terhadap lembaga pengumpul zakat tersebut. Disisi lain pajak yang juga merupakan salah satu cara untuk mensejahterakan rakyat mempunyai fungsi yang hampir sama dengan zakat.

Namun perkembangan zakat tidak sebaik dengan pajak karena zakat ditunaikan berdasarkan iman atau kesukarelaan, disamping tidak ada kontrol dan pemberian sanksi bagi pelanggarnya, maka pembayarannya pun tidak jarang terabaikan atau tergantung pada tingkat ketaqwaan seseorang. Dalam hal ini, zakat kalah pengaruh oleh pajak. Hal inilah yang seringkali menjadi 
kendala utama dalam meningkatkan jumlah penerimaan zakat pada lembaga-lembaga pengumpul zakat. Oleh karena itu diperlukan upaya mensinergikan zakat dan pajak untuk sebagai penerimaan yang berbeda secara prinsip tetapi memiliki kesamaan secara tujuan.

Beberapa sinergi yang dapat dilakukan adalah pertama, kolaborasi program sosialisasi dan edukasi antara pemerintah melalui Dirjen Pajak dan BAZNAS sebagai amil resmi zakat nasional. kedua, penyediaan fasilitas pengelolaan zakat di Kantor Pelayanan Zakat (KPP). Ketiga, koordinasi yang baik antara otoritas pajak. Keempat, penerapan zakat sebagai pengurang pajak secara langsung dan kelima, pengelolaan zakat langsung di bawah pemerintah.

\section{Daftar Pustaka}

Afriyandi, Yuli, Sinergitas Pajak dan Zakat dalam Keuangan Publik Islam(Analisis Historis dan Kondisi Kekinian, Jurnal Rasail, Vol 1, No 2, 2014.

Firmansyah, Zakat Sebagai Instrumen Pengetasan Kemiskinan Dan Kesenjangan Pendapatan, jurnal Ekonomi dan Pembangunan Vol 21, No.2, Desember 2013.

Gusfahmi, Rekonstruksi Praktek Zakat dan Pajak Untuk Menanggulangi Kemiskinan, Jurnal Pemikiran dan Gagasan Vol II, 2009

Mas'udi, Masdar Farid, Pajak Itu Zakat: Uang Allah untuk Kemaslahatan Rakyat, Bandung: Mizan Media Utama, 2010.

Salamah, Siti Ummu, Relasi Zakat dan Pajak: Studi Kasus Badan Amil Zakat Nasional Kabupaten Malang dan Kantor Pelayanan Pajak Pratama Kepanjen Malang, Jurnal Hukum dan Syariah Vol.6 No 1, 2015.

Yanah, Strategi Pengentasan Kemiskinan di Indonesia Melalui Sinergi Antara Bank Syariah dan Baznas, jurnal ekonomi vol.2 No.3, Mei-Agustus 2014.

Undang-Undang Nomor 28 Tahun 2007 tentang Perubahan Ketiga Atas Undang-Undang Nomor 6 Tahun 1983tentang Ketentuan Umum dan Tata Cara Perpajakan LN. Tahun 2007 No. 85

www.bps.go.id

http://www.republika.co.id/berita/jurnalisme-warga/wacana/17/08/30/ovibjm396-sinergipelayanan-zakat-dan-pajak

https://www.kompasiana.com/zayfawwaz/59a581b0f133440ba521f482/sinergitas-pajak-danzakat-dalam-keuangan-islam 